\title{
VISIBILITY AND INVISIBILITY: EXPLORING THE REPRESENTATION OF WOMEN AND MEN IN IRISH POLITICS. THE EXAMPLE OF THE 2011 BROADCASTS
}

\author{
Author: MARTÍNEZ LIROLA, María \\ PhD - Universidad de Alicante (España) - Research Fellow, Department of Linguistics and Modern Lan- \\ guages, University of South Africa (UNISA) - maria.lirola@ ua.es
}

\section{Resumen}

Aunque la situación socio-económica de Irlanda ha mejorado en la última década, la realidad de las mujeres continúa siendo distinta a la de los hombres y hay ciertas limitaciones en sus derechos. Las mujeres siguen estando infrarrepresentadas en la política irlandesa con algunas excepciones. Sin embargo, en las últimas elecciones, algunas se presentaron como candidatas a la presidencia y también a optar a ser primera ministra. En este sentido, este artículo es una contribución al estudio de la representación de las mujeres en la campaña política del año 2011 . Tanto las elecciones generales como las presidenciales son objeto de análisis. Nuestro corpus consiste en los videos políticos usados por los principales partidos políticos (Fianna Feil, Fine Gael, Sinn Fein, entre otros).

Con respecto a la metodología, se combinará el análisis crítico del discurso y el análisis crítico del discurso multimodal con el fin de observar la representación de los/as políticos/as como actores sociales (van Leeuwen, 2008) y considerar las posibles diferencias entre las mujeres y los hombres políticas/os. El estudio tratará de observar si hay tantas mujeres como hombres en los videos de las elecciones de 2011 en Irlanda y prestará atención al modo que se las representa el los videos objeto de estudio. El análisis mostrará que los/as políticos/as son representados/as como élite, que predomina la representación positiva y que las mujeres aparecen infrarrepresentadas en la política irlandesa, hecho que pone de manifiesto que la participación de las mismas en la política sigue siendo un reto para la democracia debido a que su representación o papel no es igual al de los hombres.

\section{Palabras clave}

Multimodalidad, videos políticos, análisis crítico del discurso, Celtic Tiger.

\begin{abstract}
Although the socio-economic situation of Ireland has improved in the last decade, the situation of women continues to be unequal to men and there are certain limitations in their rights. Despite well-known exceptions, women have tended to be underrepresented in Irish politics. However, in the last elections some of them decided to run for the Republic's presidency as well as to become the first female Irish Prime Minister. In this sense, this research paper will try to contribute to the representation of women in the 2011 campaigns. Both general and presidential referendums will be under analysis. Our sample will consist of the most representative TV broadcasts of the main political parties (i.e. Fianna Feil, Fine Gael, Sinn Fein, among others).

As regards methodology, we will aim for the combination of critical discourse analysis and multimodal critical discourse analysis in order to observe the main visual representation of politicians as social actors (van Leeuwen, 2008), and consider the possible similarities and differences between women and men politicians. The study aims to observe if there are as many women as men politicians in the broadcasts of the 2011 electoral campaigns in Ireland and to pay attention to the way women and men politicians are portrayed in the broadcasts under analysis. The analysis will show that politicians are portrayed as elite individuals, that there is a general positive representation of the candidates and that women are underrepresented in Irish politics, which points out that it continues being a challenge for democracy the participation of women in politics since their representation or role is not equal compared to men.
\end{abstract}

\section{Key words}

Multimodality, broadcasts, critical discourse analysis, Celtic Tiger period. 


\section{Introduction and objectives}

The Republic of Ireland experienced a socioeconomic growth during the period known as Celtic Tiger, which made the country increase its economy and to be of the prosperous countries in Europe (Baccaro \& Simone, 2004; Darmody, Tyrrell \& Song, 2011), as Gaughan and Garre (2011, p. 270) makes clear: "Indeed, it is undeniable that for a few years the economy expanded tremendously within the southern jurisdiction and some Irish citizens have experienced the 'best of times', even if the benefits of economic growth have never been shared equitably". In this sense, it is necessary to think about the identity of Irish citizens (Conway, 2006; Phelan, 2007), their representation in discourse and the possible differences between the representation of women and men. Although the situation of Ireland has improved in the last decade, the situation of women continues to be unequal to men and there are certain limitations in their rights such as the choice of having an abortion (Gaughan \& Garre, 2011, p. 271).

Understanding the relationships between speakers, language and context is essential in order to deconstruct what happens in society at all levels (economic, social, educational, political, etc.). The discourse used by any person has an influence in her/his context. However, if discourse is used with people who have power such as politicians, the influence of this discourse is multiplied because it has an effect on more people due to the fact that political leaders are public figures well known in the countries where they are politicians and also internationally. For this reason, we will approach the representation of women and men politicians in broadcasts (i.e. political advertising videos) produced for the last electoral campaigns in Ireland (2011) in order to understand how language and image work and how meanings are produced in order to persuade the audience to vote one political party or another.

Our analysis has the purpose of exploring discourse and its relation to power as far as the representation of women and men in the said broadcasts. Following van Leeuwen and Jewitt (2001, p. 7), the analysis based on multimodal discourse analysis that we will present in this paper intends to show that "[...] text analysis can show what representations include and exclude, what they prioritise and make salient, and what differences they construct between different people, places and things."

Before the Celtic Tiger, women and their work were invisible and men were the ones earning money. Women were relegated to the domestic sphere as mothers and caregivers, that is, their jobs were associated with the domestic sphere, especially migrant women (Kennedy, 2006). In a way, they were invisible as workers since they did not take positions in the public places. In Conlon's words (2007, p. 48-49):

\begin{abstract}
"As in most European nations, women in Ireland have entered the paid labor force in significant numbers (see O'Connor 2001; and O'Connell 2001) while immigrants, predominantly women, take up the tasks associated with the social reproduction of the domestic sphere (see Conroy, 2003). Ironically then, as many Irish women have been thrown into the public domain of Celtic Tiger Ireland as independent professionals, immigrant women take up the historically nationalist ideological position of Irish women as caregiver and social/cultural reproducers of the nation-state”.
\end{abstract}

We aim to present an analysis of how women and men are represented in Irish politics paying attention to the political broadcasts used in the 2011 campaign. These broadcasts are produced by political parties and therefore, they are an example of political propaganda. We intend to explore the way in which visual resources combine in these texts to create meaning, as Baldry and Thibault (2006, p. xv) point out, multimodality " $[\ldots]$ is a useful yardstick for measuring and assessing the diversity of ways in which texts and their associated meaning-making practices are the results of the ways in which semiotic resources of various kinds work in partnership to create the meanings that we attribute to texts."

Once the different resources to create meaning in the broadcasts are analysed we will refer to the relationship between texts and society and to how this has an effect in the way readers perceive these texts because the study of multimodal resources must always go in conjunction with the study of the context in which the texts are produced and analysed, as Baldry and Thibault (2006, p. 3) put it: "The important point is that texts are embedded in, and 
help to constitute, the contexts in which they function. Texts are thus inseparable parts of meaningmaking activities in which they take part".

Our main hypothesis is that women are underrepresented in Irish politics. For this reason a critical discourse analysis will be done to the political broadcasts used in the 2011 Irish campaigns in order to observe women's representation and to confirm or deny the said hypothesis. The main research questions we will try to answer with the analysis are the following: Are there as many women as men politicians in the broadcasts of the 2011 electoral campaigns in Ireland? And how are women and men politicians portrayed in the broadcasts of the 2011 electoral campaigns in Ireland?

After this introduction, this paper is organised in the following sections: the next section concentrates on the aim, data and methodology of this study; political discourse and multimodal discourse analysis are discussed in the section where the theoretical background is presented; this is followed by the analysis of politicians as social actors in a sample of political broadcasts. The article ends with a discussion and the conclusions of the study.

\section{Aim, data and metodology}

This is an interdisciplinary study that combines different disciplines such as political communication, linguistics, media studies, among others. The main aim of this research is to observe the representation of women and men in the 2011 Irish electoral campaigns using critical discourse analysis as a perspective in order to observe the way politicians are portrayed as social actors (van Leeuwen, 2008).

The corpus of examples consists on most of the broadcasts produced by the political parties for the elections that took place in 2011 , i.e., 7 broadcasts of the Presidential Elections (2 woman as candidates) and 12 broadcasts of the General Elections (there are no women as candidates). The broadcasts will be analysed as multimodal texts and as effective types of propaganda.

We understand discourse as social practice and therefore the political video is seen as social practice. Considering the critical discourse analysis model proposed by van Leeuwen (2008), we will study the representation of politicians as social actors in order to observe the visibility or invisibility of women politicians compared to men in the 2011 Irish electoral campaign. Following van Leeuwen (2008), social actors can be included or excluded in discourse. The fact that women are underrepresented in the broadcasts under analysis shows that women are deprived of power in the political sphere.

\section{Theoretical background}

This paper focuses on the broadcasts produced for the last electoral campaigns in the Republic of Ireland. For this reason it is appropriate that the theoretical background of this paper deals with political discourse and multimodal discourse analysis. Consequently, this research is understood as an interdisciplinary study in which political communication, discourse analysis, media studies and other disciplines combine in order to understand the messages present in the broadcasts (Getzer \& Lauerbach, 2007), as Kaid (2004a, p. xiii) makes clear:

"Although political communication can trace its roots to the earliest classical studies of Aristotle and Plato, modern political communication research is very much an interdisciplinary field of study, drawing on concepts from communication, political science, journalism, sociology, psychology, history, rhetoric, and other fields".

Political discourse analysis has expanded in the last decades (Álvarez, Fernández \& Íñigo, 2009; Chilton, 2004a \& 2004b; Chilton \& Schèaffner, 2002; Fairclough \& Fairclough, 2012; Geis, 1987; van Dijk, 2002). These studies coincide in pointing out that political language functions to influence political thought. In addition, they suggest that it is important to understand what it is possible to do with language in general in order to observe what politicians do with language. We are especially interested in political advertising (Kaid, 2004b; Kaid \& Holtz- 
Bacha, 2006a; Johnston, 2006)due to its importance in the distribution of political power:

"Political advertising understood here only appears in systems in which the distribution of political power is contested and determined in elections and in which parties or candidates compete with each other. Political advertising, then, is a means through which parties and candidates present themselves to the electorate, mostly through the mass media”. (Kaid \& Holtz-Bacha, 2006b: 3)

Paying attention to the discourse used by politicians involves taking into consideration the messages they communicate, the audience to whom they are addressed, the politician as sender, the channel used to communicate the message and the context in which the message is produces, as van Dijk (2006, p. 733) points out: "Political discourse, thus, is not only defined in terms of political discourse structures but also in terms of political contexts". In this sense, political discourse can concentrate on the analysis of different genres: posters and other electoral campaigns materials such as propaganda leflets (Aulich \& Sylvestrová, 1999; Martínez Lirola, 2014), elections and parliamentary debates (Luengo, 2011; Reinemann \& Wilke, 2007; van Dijk, 2005), interviews to politicians or speeches (Chen, 2007; Kyrala, 2010), etc.

International studies make clear that women are underrepresented in politics (Archenti \& Tula, 2008; Bird, 2003; Celis et al., 2014; Paxton \& Hughes, 2007). They do not have as many powerful positions as men and their role in politics is secondary, normally as secretaries of the political parties or as candidates of small cities or towns, as Verge and de la Fuente (2014, p. 76) state:

"[...]that political parties largely remain inhospitable spaces for women. While unequal patterns of office distribution can be fixed through gender quotas, this 'simple' solution cannot automatically address the complexity of gender power relations within parties. Irrespective of parties' commitments to women's representation, men still maintain power over women through a variety of informal situations".

Although there have been advances in the representation of women in politics, it has been difficult for them to gain admission to the "elite of elite" (Howard Davis, 1997). The participation of women in politics continues being a challenge for democracy since their representation or role is not equal compared to men. Moreover, there is a tendency to criticise women who are in a position of power, as Howard Davis (1997, p. 21) makes clear: "Many women in positions of power-such as Thatcher, Gandhi, and Richards-are often criticised, then, for not being concerned with advancing women's rights or for adopting masculine leadership styles. Women in appointive process, often draw fire because of the potentially symbolic nature of the appointive process, [...]".

Women's participation to the decision-making of parties is limited and their access to influential positions within political parties is constrained. If we ask ourselves why there are so few women elected in Ireland and why they have difficulties to find a position in the 'elite of elites' and be influential in politics, the answer is not clear although it seems that they can considered vote losers in Ireland, in Stokes' words (2005, p. 158): "[...] most of the women who run for office do so either on the tickets of unelectable parties, or for electable parties but in unwinnable seats. Women candidates are still believed to be vote losers, and the political parties that act as gatekeepers are reluctant to select women". This statement shows the persistence of patriarchy and the evident predominant visibility of men in the public sphere, in the positions of power. In this sense it is necessary to reivindicate a 'politics of presence' (Stokes, 2005, p. 21) where women have access to power in a similar way as men and they are visible in the political sphere.

There are some studies that have paid attention to the 2011 election campaigns in Ireland (Hutcheson, 2011; Marsh \& Mikhaylov, 2012). However, none of them have paid attention to the political videos. The broadcasts under analysis are examples of political advertising as already mentioned (Kaid, 2004; Kaid \& Holtz-Bacha, 2006a); they are multimodal texts. For this reason, the following paragraphs of this literature review section concentrate on multimodal discourse analysis. The increasing use of multimodal texts (those that use more than one mode of 
communication) implies the development of multimodal discourse analysis (hereafter MDA) in order to understand the way the different semiotic resources combine and contribute to create meaning in society. Machin (2007, p. $\mathrm{x}$ ) points out that what is special about the multimodal approach to communication is "the idea that all modes need to be considered with the same kind of detail, as semiotic systems in themselves, whose potential choices, patterns and grammar can be described and documented".

Following Halliday (1978, p. 27), we understand language as 'meaning potential' - what the speaker can do or mean, which implies that out of the different choices that are possible in language, the speaker selects the most appropriate according to the communicative situation or the functions that language has in context. The twenty-first century society is characterized by the use of different modes to express meaning, i.e., texts combine resources (visuals, language, music, graphs, etc.) in order to create an effective message.

In the last decades, the theory of multimodality has been developed through the work done by Kress and van Leeuwen $(1996,2001,2006)$ and other authors (Baldry \& Thibault, 2006; Bezemer \& Jewett, 2010; Bowcher, 2012; Jewitt, 2009; Norris, 2004; Norris \& Jones, 2005; O’Halloran, 2011; O’Toole, 1994, 2010; Royce \& Bowcher, 2007, Scollon, 2001; Scollon \& Scollon, 2004, among others). The work of Machin (2007), O'Halloran and Smith (2011) and van Leeuwen (2008) has contributed to the development of multimodality from a critical discourse perspective. Their work is based mainly on social semiotics; we are especially interested in this approach because of its critical perspective that makes possible to deconstruct meanings and establish a connection between them in the context they are used. They have contributed to understand how different modes of communication (language, image, graphics, sound, music, gestures, etc.) create meanings.

These modes are the different semiotic resources that contribute to the development of meaning through one of them or through the combination of several used simultaneously. The image pays a very important role in multimodal communication due to its importance in catching the audience's attention (Jewett, 2009; Kress \& van Leeuwen, 2006; Kress, 2010; Unsworth, 2010). Multimodal data are diverse, for example in this paper we use political videos, which implies that MDA faces different challenges, in Flewitt et al.'s words (2009: 40):

"The diversity of multimodal data presents particular challenges, requiring descriptive and analytic tools that can both accomodate their variability and reflect their complexity. Transcription, however, still relies largely on the use of written script. As a result, the question of whether language-based techniques are a sufficient and acceptable way to mediate multimodal meanings, or whether multimodal data require a transformation of the tools used to describe them remains as yet unresolved."

Consequently, the eclectic and interdisciplinary nature of MDA (Khosravinik 2010, p. 55) offers the possibility of integrating different disciplines (political sciences, communication or linguistics among others) to analyse multimodal texts and that is why MDA is used in this paper in order to deconstruct the main characteristics of political discourse in the political broadcasts that are used as corpus. In this sense, this paper faces the challenge of incorporating different methodologies and theoretical backgrounds in order to analyse the main characteristics of political videos and to be aware of the ideology that they portray, in this case in the last elections in Ireland.

The political broadcast is an example of multimodal text in which language integrates with other resources. In this sense, the analysis of videos is essential to understand the range of different human discourses used to persuade the audience to vote to one political party instead of another. In addition, the analysis of multimodal texts favour an interdisciplinary approach to the analysis of texts as we do in this paper combining the use of content analysis used in social sciences (i.e. in political sciences) and discourse analysis or more specifically MDA.

It is well known that CDA intends to uncover the hidden ideology behind texts. Consequently, using 
multimodal texts such as broadcasts requests the approach of MDA because the hidden meanings will be deconstructed observing the language used in the broadcasts and the visuals. For this reason, the combination of content analysis with MDA allows understanding the broadcasts as a whole where meaning is created through the combination of different resources.

Choosing MDA as a theoretical framework allows understand how texts make meaning and the different communicative forms in which those meanings are conveyed (language, image, sound, etc.). Deconstructing how meaning is created allows understand how audiences engage with the texts under analysis. Moreover, MDA allows establish a relationship between the multimodal characteristics of the text and the social, political and economic contexts that frame the texts (O' Halloran \& Smith, 2011).

We have chosen electoral campaigns broadcasts as an example of political propaganda and multimodal texts in which politicians communicate different messages through language and image in order to present themselves as elite individuals, as van Dijk (1998, p. 25) states: "Thus, campaigning politicians will speak about themselves as candidates, about the elections, about voting for them, and the policies they promise to support when elected. They speak about opponents and political enemies and about the bad politics and policies of previous presidents, governments or parliaments".

Therefore, this study takes into account what politicians do with language and other semiotic resources in the broadcasts used to promote themselves as candidates and to persuade the audience to vote them. This portrays an ideology based on the main ideas that support the programmes of each political party and of the importance of the political leader as someone who belongs to an elite and therefore has power and influence among citizens (van Dijk, 2006). The analysis of these resources will make possible to uncover the different mechanisms of propaganda, demagogy or manipulation that are used by politicians in their public discourse. Consequently, the relationships between power, ideology and political discourse will be established.

The analysis of the broadcasts based on political discourse analysis and multimodal discourse analysis will allow the deconstruction of the power politicians have through the different semiotic resources under analysis and approach the ideology of politicians as elite individuals in a democratic society such as Ireland in the twenty-first century.

\section{Analysis: politicians as social actors in a sample of political broadcasts}

In order to study how politicians are visually depicted, we will follow van Leeuwen's (2008) classification to observe the visual representation of the political leaders under analysis. Van Leeuwen (2008, p. 28ff) proposes some general categories and some subtypes, which sometimes are complementary, to refer to social actors in discourse: exclusion or inclusion. Inside inclusion, the following types are distinguished: 1) role allocation (agent or patient), 2) generalisation and 3) specification (generic or specific reference, i.e., representation as classes or as individuals); 4) assimilation (representation of people in groups), 5) association (groups of social actors) and 6) dissociation (unformed associations); 7) indetermination (unspecified representation of social actors) and 8) differentiation (specification of the different social actors); 9) nomination (reference to the unique identity of social actors) and 10) categorisation (identities and functions shared with others); 11) functionalization and 12) identification (reference to social actors in terms of something they do or what they are); 13) personalization and 14) impersonalisation (representation of social actors as human beings or not); and, finally, 15) overdetermination (representation of social actors as participating in more than one social practice).

Out of the different categories already mentioned, there are some that are used recurrently for the representation of the candidate as the political leader: 
their role is active in discourse since they are the agents of the actions by speaking and explaining their programs in the broadcasts; they are also represented as specific social actors because although they appear with other people in most of the videos there are scenes in which they appear alone and they are never confused with other people; the previous category is related to that of differentiation because each politician is specified inside the different social actors that appear in the videos. Moreover, the political leader is portrayed " $[\ldots]$ in terms of their unique identity, by being nominated [...] (van Leeuwen, 2008, p. 40) because their names appear several times in most of the broadcasts. Finally, the categories of functionalization and identification are also relevant for the analysis of the political leader in the broadcasts because there is no doubt of the reference to their being politicians, i.e., of making of politics a way of living. The following table shows the main characteristics of the political leaders following the categories proposed by van Leeuwen (2008, p. 28ff) in the General and Presidential Elections.

Table 1: Main characteristics of the political leaders in the General and Presidential Elections broadcasts.

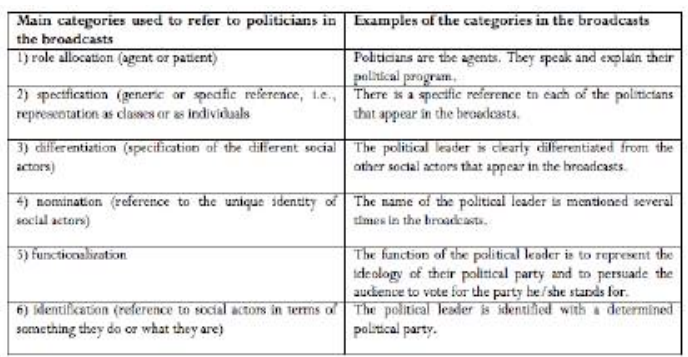

We are interested in the representation of women and men politicians in the last electoral campaigns in Ireland. In addition, we are also interested in the representation of other women and men apart from the politicians that appear represented in the broadcasts produced for the 2011 Presidential and General Elections. This analysis will show that women are underrepresented, which points out that it is necessary to continue advancing in the representation of women in Irish politics and in all areas of society as the analysis presented in the following paragraphs will make clear.
Table 2 shows the number of men and women who appear as political leaders in the broadcast under analysis:

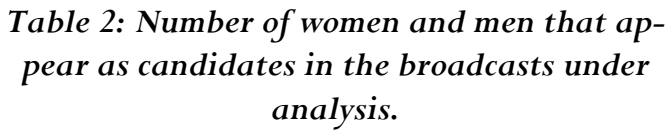

Table 2: Number of women and men that appear as candidates in the broadcasts under analysis.

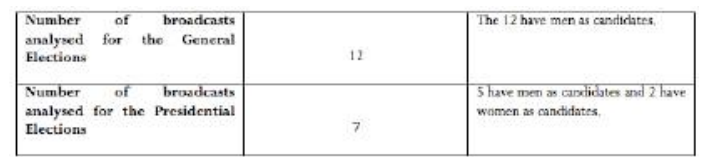

Moreover, van Leeuwen (2008, pp. 138-141) pays attention to social distance, social relation and social interaction. Although there are different patterns in the broadcasts analysed, the representation of social actors that appears more often in order to persuade the audience to vote for the political party that the candidate represents is the following: the predominant distance consists on a close shot as a way to show affection to the audience and establish a close relationship with them. When concentrating on social interaction, it is outstanding that the main pattern observed in the multimodal texts under study makes explicit a direct address to the audience since the politicians portrayed look directly at the viewers, requesting their vote, which could be considered a symbolic demand.

As regards social relation, we observe a preference for the frontal angle indicating that the politicians represented have power and are involved in the action of persuading their audience to listen to their political message and to vote for their party. On the one hand, the vertical angle is understood to be connected with power relations since human beings can be looked from below, above or at eye level (there is a strong preference for this last option in the broadcasts analysed). On the other hand, the horizontal angle has to do with seeing people frontally or from the side suggesting that the person represented, in this case the political candidate is involved or detached from the action (van Leeuwen, 2008, p. 139). The political leader is normally represented frontally in the videos suggesting that he is involved with the problems and social situation of the audience. In a nutshell, the main patterns observed in the videos are involvement (frontal angle) and equality (eye level). The following 
table shows the main patters of the visual representation of social actors in the videos for the General and Presidential Elections following van Leeuwen (2008, p. 138-141). The fact that two women compared to five men were candidates for president in the last elections in Ireland shows that there are inequalities of gender in the way power is performed.

We would like to devote special attention to the video

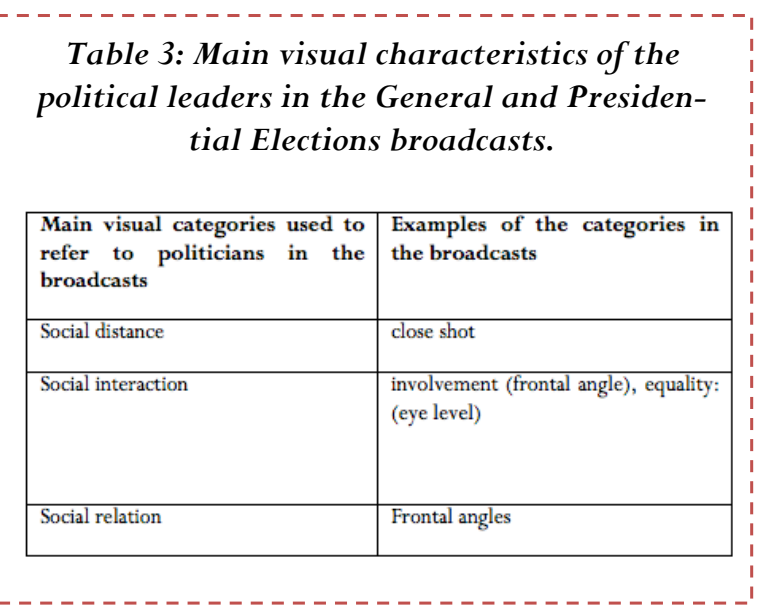

used by Mary Davis to advertise herself as a candidate for the Presidential Elections not only for being one of the two videos having a woman as a candidate but also because it is a very good multimodal text that combinesdifferent resources to express meaning in a very adequate way. Her presence at the beginning and at the end of the video and the fact that her voice is used throughout the whole broadcasts although there are other human beings represented is a very good strategy used to establish a close contact with the audience. The way she establishes an imaginary relationship with the viewer is very clear: she and all the other participants in the video that she stands for interact directly with the audience because this is an example of demand images, where she looks directly and addresses the audience directly in her speech requesting a response.

The vertical angle is used in the video to see Mary Davis and the other social actors represented at eye level; in addition, the horizontal angle is used to see the persons in the video frontally. Moreover, all the depicted people look directly at the audience, which implies that they interact directly with the audience and they invite them to be one of them: a woman, a man, a mother, a young person, a child, among others. Presenting every social actor talking and foregrounded make the audience perceive them as active citizens who contribute to the creation of a new plural Ireland where everybody counts, as van Leeuwen (2008, p. 33) explains: "Activation occurs when social actors are represented as the active, dynamic forces in an activity, passivization when they are represented as "undergoing" the activity, or as being "at the receiving end of it".

This video is unique in the 2011 electoral campaign because it is the only one that offers a very clear example of integration and of a plural Ireland for different reasons: the different ages of the social actors represented (there are children and also elderly people) and their different appearances (there are blond people, dark haired, people with classical types and people who were casual clothes, etc.); the inclusion of minorities is made explicit by representing a woman with Down Syndrome; there are also references to other minorities such as gays or lesbians. It is outstanding that women and men are represented in an equal way.

One of the striking characteristics of the video is that no matter who appears foregrounded, it is always the voice of Mary Davis the one used by the person represented. All the social actors appear alone (with the exception of a mother with her child, which is another example of the inclusion of the reality of motherhood), which contributes to adding a leading role to the person who represents a particular group of society at a time. Each individual is highlighted and given prominence by presenting them as "[...] subjects addressing the viewer with their gaze and symbolically engaging with the viewer in this way" (van Leeuwen, 2008, p. 141).

Moreover, it is not only visually that the candidate for president shares her power with the Irish society but also linguistically since the beginning of the video Davis points out that she stands for the individuals who are part of the Irish society: "I am Mary Davis and I am not asking you to vote for me on October 27. I am asking you to vote for what I stand for and what I stand for is you. Ireland [...]". Similarly, the video ends with a 
clear enumeration of what Davis intends to be for each individual in Ireland, and the repetition of the personal pronoun you suggests that she wants to share her power: "Your power, your values, your voice, I am Mary Davis and I am asking you to choose me to be your voice $[\ldots]$ ".

The video already analysed contrasts with the other broadcasts used by politicians to advertise themselves in 2011. The contrast is very clear with the video in which the political leader appears alone in his office, as it happens in the cases of David Norris and Sean Gallagher. Both politicians appear represented in their offices (there is one scene in which Gallagher appears outside his office with his wife) and they establish interaction with the audience by looking directly to the camera; the vertical angle shows both politicians at eye level and the horizontal angle makes clear that we see them frontally, which shows involvement with the listeners. Consequently, there is no doubt that both interact by looking at their intended audience, which can be interpreted as a symbol of demanding to be voted in the elections. Sean Gallagher is represented holding his arms most of the video, which can be interpreted as a gesture showing that he is confident and that he has power.

\section{Discussion}

The media shapes our thinking and can contribute to socio-political change by promoting criticism and reflections about the social realities it transmits in the different pieces of news (van Dijk, 2002). In this sense, the broadcasts analysed have an effect on how women and men politicians are constructed as political candidates, which shapes public opinion and contributes to the construction of political power through the representation of men as the majority of the leaders in the 2011 Irish general and presidential electoral campaigns.

The analysis of the broadcasts presented in the previous section shows that women are underrepresented in Irish politics since out of the different broadcasts analysed there are only two having a woman as political leader for the Presidential Elections, i.e., Mary Davis and Dana Rosemary Scallon. The said analysis shows that there is a relationship between texts (in this case the political broadcasts) and context, i.e., from the scarce representation of women as political leaders we can deduce that they do not have an outstanding role in many areas of society; in this way, the political video is understood as a sample of discourse that incorporates not only language and visual aspects but also context, following Woods (2007, p. x):

"Discourse is, at the very least, language plus contextby which I mean the context that we bring with us when we use language; the context that includes our experience, assumptions and expectations; the context we change (and which is itself changed) in our relationships with others, as we both construct and negotiate our way through the social practices of the world we live in.”

The complex nature of the political broadcast as a multimodal text requests the development of software and computational tools that allow a deeper analysis of the political broadcasts. In other words, further development of multimodal corpus linguistics is necessary in order to provide a more systematic and objective analysis that facilitates the work of researchers and the understanding of the main multimodal strategies used to persuade readers to vote for one candidate instead of another.

The political video is a socially constructed multimodal text whose purpose is to offer a persuasive representation of political leaders and to inform the audience about the party's program. Analysing the broadcasts under analysis is a dynamic activity that understands the video as a dynamic multimodal text. Therefore, this analysis pays attention to what the multimodal text does in society instead of just describing what it says. In this sense, the broadcasts are ideological artefacts whose main objective is to persuade through the different linguistic and visual characteristics chosen by the video's producers. 


\section{Conclusions}

The analysis of the political broadcasts presented in this article shows that broadcasts are understood as dynamic multimodal texts in which the different elements that appear in them (social actors represented, angles, gazes, distance, language, etc.) communicate. The broadcasts analysed portray politicians as an elite group; there is a general positive representation of the candidates and a general exclusion of women as protagonists of the broadcasts. In addition, the analysis done in this article makes clear that women are underrepresented in politics because they are not very visible in the broadcasts used in the 2011 general and presidential campaigns. This is an obvious example of the persistence of patriarchy. It exists at all levels of society but political discourse as one of the most representative examples of elite discourse is not an exception.

Women and men are not equal in the use of political power because there are fewer women in politics and although women's representation in politics has increased in the last decade, their role and responsibility are normally inferior to those of men basically because they are not the favourite candidates in the elections or because they are given secondary positions. In this sense, it is necessary to develop a 'politics of presence' where the representation of women and men is equal in politics. If women are equally represented in the discourse of elites it is more likely that they can promote politics that highlight the visibility of women at all levels of society.

\section{References}

- Álvarez-Benito, G., Fernández-Díaz, G. \& Íñigo-Mora, I.M. (Eds.) (2009). Discourse and Politics. Newcastle upon Tyne: Cambridge Scholars Publishers.

- Archenti, N. \& Tula, M.I. (Eds.) (2008). Mujeres y política en América Latina. Sistemas electorales y cuotas de género. Buenos Aires: Heliasta.

- Aulich, J. \& Sylvestrová, M. (1999). Political Posters in Central and Eastern Europe, 1945-95: Signs of the Times. Manchester: Manchester University Press.

- Baccaro, L. \& Simone, M. (2004). The Irish social partnership and the 'Celtic Tiger' phenomenon. Discussion Paper Series, 154.

- International Labour Organization, Geneva, Switzerland.

- Baldry, A. \& Thibault, P.J. (2006). Multimodal Transcription and Text Analysis. London: Equinox.

- Bateman, J. (2008). Multimodality and Genre: a Foundation for the Systematic Analysis of Multimodal Documents. London: Palgrave Macmillan.

- Bezemer, J. \& Jewett, C. (2010). Multimodal Analysis: Key Issues. In L. Litosseliti,
(Ed.), Research Methods in Linguistics (pp. 181-197). London: Continuum.

- Bird, K. (2003). Who are the women? Where are the women? And what difference can they make? Effects of gender parity in French municipal elections. French Politics, 1(1), 5-38.

- Bowcher, W.L. (Ed.). (2012). Multimodal Texts from Around the World: Cultural and Linguistic Insights. London: Palgrave.

- Celis, K., Erzeel, S., Mügge, L. \& Damstra, A. (2014). Quotas and intersectionality: Ethnicity and gender in candidate selection. International Political Science Review, 35(1), 41-54.

- Chen, L. (2007). Negatives and positives in the language of politics attitudes towards authority in the British and Chinese press. Journal of Language and Politics, 6(3), 475-502.

- Chilton, P.A. (2004a). Political Discourse Analysis. London: Routledge.

- Chilton, P.A. (2004b). Analysing Political Discourse: Theory and Practice. London: Routledge.

- Chilton, P.A. \& Schèaffner, C. (Eds.) (2002). Politics as Text and Talk: Analytic Approaches to Political Discourse. Amsterdam/Philadelphia: John Benjamins. 
- Conlon, D. (2007). The Nation as Embodied Practice: Women, Migration and the Social Production of Nationhood in Ireland. Ph.D. Thesis. New York: City University of New York.

- Conroy, P. (2003). Migrant Women - Ireland in the international division of care. In R. Lentin \& E. Luibheid (Eds.), Women's Movement: Migrant Women Transforming Ireland'. Selection of papers from a conference held in Trinity College Dublin, 2021 March 2003 (pp. 18-25). Dublin: MPhil in Ethnic and Racial Studies, TCD.

- Conway, B. (2006). Who do we think we are? Immigration and the discursive construction of national identity in an Irish daily mainstream newspaper, 1996-2004. Translocations: The Irish Migration, Race and Social Transformation Review, 1(1), 7694.

- Darmody, M., Tyrrell, N. \& Song, S. (Eds.) (2011). The Changing Faces of Ireland. Exploring the Lives of Immigrant and Ethnic Minority Children. Rotterdam: Sense Publishers.

- Fairclough, N. (1995). Critical Discourse Analysis: The Critical Study of Language. London: Longman.

- Fairclough, I. \& Fairclough, N. (2012). Political Discourse Analysis. A Method for Advanced Students. London/New York: Routledge.

- Fetzer, A. \& Lauerbach, G.E. (2007). Introduction. Political Discourse in the Media. Crosscultural perspectives. In A. Fetzer \& G.E. Lauerbach (Eds.), Political Discourse in the Media. Crosscultural Perspectives (pp. 3-28). Amsterdam/Philadelphia: John Benjamins.

- $\quad$ Flewitt, R., Hampel, R., Hauck, M. \& Lancaster, L. (2009). "Multimodal data collection and transcription”. In C. Jewitt, Carey (Ed.), The Routledge Handbook of Multimodal Analysis (pp. 40-53). London: Routledge.

- Gaughan, L. \& Garre, P.M. (2011). The 'most twisted and unaccountable force in the state'? Newspaper accounts of social work in the Republic of Ireland in troubled times. Journal of Social Work, 12(3), 267-286.

- Geis, M. L. (1987). The Language of Politics. New York: Springer.
- Halliday, M.A.K. (1978). Language as Social Semiotic: The Social Interpretation of Language and Meaning. London: Edward Arnold.

- Howard Davis, R. (1997). Women and Power in Parliamentary Democracies. Cabinet Appointments in Western Europe, 1968-1992. Nebraska: University of Nebraska Press.

- Hutcheson, D.S. (2011). The February 2011 Parliamentary Election in Ireland. IBIS Working Paper no. 109. Working Papers in British-Irish Studies. Dublin: Institute for British-Irish Studies, University College Dublin.

- Jewett, C. (Ed.). (2009). The Routledge Handbook of Multimodal Analysis. London: Routledge.

- Johnston, A. (2006). Methodologies for the Study of Political Advertising. In L.L. Kaid \& C. Holtz-Bacha (Eds.), The Sage Handbook of Political Discourse (pp. 15-34). London: Sage Publications.

- Kaid, L. L. (2004a). Introduction and Overview of the Field. In L.L. Kaid (Ed.), Political Communication Research (pp. xiii-xviii). London/New Jersey: Lawrence Erlbaum Associates.

- Kaid, L.L. (2004b). Political advertising. In L.L. Kaid (Ed.), Handbook of Political Communication Research (pp. 155-202). Mahwah, New Jersey: Lawrence Earlbaum Associates, Publishers.

- $\quad$ Kaid, L.L., \& Holtz-Bacha, C. (Eds.) (2006). The Sage Handbook of Political Advertising. Thousand Oaks: Sage.

- Kaid, L.L. \& Holtz-Bacha, C. (2006). Political Advertising in International Comparison. In L.L. Kaid \& C. Holtz-Bacha (Eds.), The Sage Handbook of Political Discourse (pp. 3-13). London: Sage Publications.

- Kennedy, P. (2006). Migrant women in Ireland: Social rights and personal autonomy. Paper presented at Migrations and Social Policies in Europe. Universidad Pública de Navarra, Pamplona, Spain. 8th June 2006.

- Khosravinik, M. (2010). Actor descriptions, action attributions, and argumentation: towards a systematization of CDA analytical categories in the representation of social groups. Critical Discourse Studies, 7(1), 55-72. 
- Kress, G. (2010). Multimodality. A Social Semiotic Approach to Contemporary Communication. London: Routledge.

- Kress, G. \& van Leeuwen, T. (1996). Reading Images: The Grammar of Visual Design. London: Routledge Press.

- Kress, G. \& van Leeuwen, T. (2001). Multimodal Discourse: The Modes and Media of Contemporary Communication. London: Arnold.

- Kress, G. \& van Leeuwen, T. (2006). Reading Images: The Grammar of Visual Design (2nd ed.). London: Routledge.

- Kress, G., Jewitt, C., Ogborn, J. \& Charalampos, T. (2001). Multimodal Teaching and Learning. The Rhetorics of the Science Classroom. London: Continuum.

- Kyrala, C. (2010). Systemic linguistic analysis of samples from economic speeches by Barak Obama and John McCain. Journal of Language and Politics, 9(1), 74-95.

- Lemke, J. (1998). Multiplying Meaning: Visual and verbal semiotics in scientific text. In J.R. Martin \& R. Veel (Eds.), Reading Science (pp. 87113). London: Routledge.

- Luengo, O.G. (2011). Debates electorales en televisión: Una aproximación preliminar a sus efectos inmediatos. Revista Española de Ciencia Política, 25, $81-96$.

- Machin, D. (2007). Introduction to Multimodal Analysis, London: Hodder Arnold.

- Marsh, M. \& Mikhaylov, S., (2012). Economic voting in a crisis: The Irish election of 2011. Electoral Studies, 31(3), 478-484.

- Martínez Lirola, M. (2014). The portrayal of women's contribution to Irish society through a sample from the Irish press. Studi Irlandesi. A Journal of Irish Studies, 4, 43-58.

- O’Halloran K.L. (ed.) (2004). Multimodal Discourse Analysis. Systemic Functional Perspectives. London: Continuum.

- O’Halloran, K.L. (2008). Systemic functional multimodal discourse analysis (SF-MDA): constructing ideational meaning using language and visual imagery. Visual Communication, 7, 443-475.
- O’Halloran, K.L. (2011). Multimodal Discourse Analysis. In K. Hyland \& B. Paltridge (Eds.), The Continuum Companion to Discourse Analysis (pp. 120-137). London/New York: Continuum.

- O'Halloran, K.L. \& Smith, B. (Eds.) (2011). Multimodal Studies. Exploring Issues and Domains. London: Routledge.

- O'Connell, M. (2001). Changed utterly: Ireland and the new Irish psyche. Dublin: The Liffey Press.

- O’Connor, P. (2001). Emerging Voices: Women in Contemporary Irish Society. Dublin: Institute of Public Administration.

- Paxton, P. \& Hughes, M. (2007). Women, Politics and Power: A Global Perspective. Thousand Oak, CA: Pine Forge Press.

- Phelan, S. (2007). The discourses of neoliberal hegemony: The case of the Irish Republic. Critical Discourse Studies, 4(1), 29-48.

- Reinemann, C. \& Wilke, J. (2007). It's the debates, stupid! How the introduction of televised debates changed the portrayal of chancellor candidates in the German press, 1949-2005. Press/Politics, 12, 92-111.

- Royce, T. (2003). Intersemiotic Complementarity in Multimodal Text: An Analytical Framework. In M. Amano (Ed.), Creation and Practical Use of Language Texts. Proceedings of the Text Second International Conference Studies for the Integrated Text Science (pp. 99-109). Nagoya: Graduate School of Letters, Nagoya University.

- Royce, T.D. (2007). Intersemiotic Complementarity: a Framework for Multimodal Discourse Analysis. In T. D. Royce \& W. L. Bowcher (Eds.), New Directions in the Analysis of Multimodal Discourse (pp. 63-109). London: Lawrence Erlbaum Associates.

- Royce, T. D. \& Bowcher, W. L. (Eds.). (2007). New Directions in the Analysis of Multimodal Discourse. London: Lawrence Erlbaum Associates.

- Stenglin, M. (2009). Space Odyssey: Towards a social semiotic model of 3D space. Visual Communication, 8(1), 35-64. 
- Stokes, W. (2005). Women in Contemporary Politics. Cambridge: Polity Press.

- Unsworth, L. (2010). Resourcing multimodal literacy pedagogy. Toward a description of the meaning-making resources of language-image interaction. In T. Locke (Ed.), Beyond the Grammar Wars (pp. 276-293). London: Routledge.

- van Dijk, T. A. (1998). What is political discourse analysis? In J. Blommaert \& C. Bulcaen (Eds.), Political Linguistics (pp. 11-52). Amsterdam/Philadelphia: John Benjamins.

- van Dijk, T. A. (2002). Political discourse and political cognition. In P. A. Chilton \& C. Schäffner (Eds.), Politics as Text and Talk. Analytical Approaches to Political Discourse (pp. 204-236). Amsterdam/Philadelphia: John Benjamins.

- van Dijk, T. A. (2005). War rhetoric of a little ally. Political implicatures and Aznar's legitimatization of the war in Iraq. Journal of Language and Politics, 4(1), 65-91.

- van Dijk, T. A. (2006). Politics, Ideology and Discourse. In R. Wodak (Ed.), Elsevier Encyclo- pedia of Language and Linguistics (pp. 728-240). Volume on Politics and Language. (2nd ed.). Oxford: Elsevier.

- Ventola, E., Cassily, C. \& Kaltenbacher, M. (Eds.) (2004). Perspectives on Multimodality. Amsterdam/Philadelphia: John Benjamins.

- $\quad$ Verge, T. \& de la Fuente, M. (2014). Playing with different cards: Party politics, gender quotas and women's empowerment. International Political Science Review, 35(1), 67-79.

- Woods, N. (2007). Describing Discourse. A Practical Guide to Discourse Analysis. Oxford: Oxford University Press.

- Van Leeuwen, T. \& Jewitt, C. (2001). Introduction. In T. Van Leeuwen \& C. Jewitt (Eds.), The Handbook of Visual Analysis (pp. 1-9). London: Sage.

\section{Forma de Citación}

MARTÍNEZ LIROLA, María: Visibility and invisibility: Exploring the representation of women and men in Irish politics. The example of the 2011 broadcasts. Revista Communication Papers, N ${ }^{\circ}$, páginas 11 a 23. Departamento de Filología y Comunicación de la Universidad de Girona. Recuperado el _ de__ de 2 de: http://www.communicationpapers.es 